\title{
Surveillance of central-line associated bloodstream infections in ICU at a Malaysian medical centre
}

\author{
A Sulong $^{1 *}$, N Awang Jalii ${ }^{1}$, R Ramli ${ }^{1}$, M Mohd Yusoff ${ }^{2}$ \\ From International Conference on Prevention \& Infection Control (ICPIC 2011) \\ Geneva, Switzerland. 29 June - 2 July 2011
}

\section{Introduction / objectives}

We conducted a prospective surveillance study to determine the incidence and epidemiology of CLABSI in the intensive care unit (ICU) at a tertiary teaching medical centre using $\mathrm{CDC}$ definition of a bloodstream infection that develops in a patient who had a central line at the time of, or within 48 hours before, the onset of the infection.

\section{Methods}

A cross section observational study was conducted in a 24-bed GICU over 10-months period from April 2008 until January 2009 among patients with central venous catheters (CVCs) inserted in the ICU or operation theatre.

\section{Results}

A total of 20 CLABSI cases were identified among 155 CVCs in 100 patients with 3106 catheter days. The overall rate of CLABSI was 6.4 per 1000 catheter-days and device-utilization (DU) ratio of 0.81 . The mean length of ICU stay for CLABSI and non- CLABSI cases was 37.2 days and 17.4 days respectively, while the median length of ICU stay for CLABSI cases was 16.0 days and for nonCLABSI cases was 10.0 days. This contributed to 6 extra days of ICU stay in CLABSI cases. CVCs inserted via the femoral vein were associated with higher infection rate of $22.2 \%$ followed by those of internal jugular vein $(15.4 \%)$ and subclavian vein (5.1\%). Gram-negative bacteria accounted for $50 \%$ of the CLABSI cases whereas grampositive cocci and fungi caused $35 \%$ and $15 \%$ of these infections respectively.
'Dept of Medical Microbiology \& Immunology, Faculty of Medicine, Universiti Kebangsaan Malaysia Medical Centre, Kuala Lumpur, Malaysia Full list of author information is available at the end of the article

\section{Conclusion}

Both of the CLABSI rate of 6.4 per 1000 catheter-days and DU ratio of 0.81 were above the $90^{\text {th }}$ percentile of the NHSN benchmark. Comparing our findings to the INNIC 2003-2008 studies with 7.4 CLABSI per 1000 catheterdays, our CLABSI rate was lower. However, our DU ratio was higher. Hence, interventions aimed at improving outcomes related to CVCs should seriously be considered.

\section{Disclosure of interest}

None declared.

\section{Author details}

1Dept of Medical Microbiology \& Immunology, Faculty of Medicine, Universiti Kebangsaan Malaysia Medical Centre, Kuala Lumpur, Malaysia. ${ }^{2}$ Dept of Anaesthesiology, Faculty of Medicine, Universiti Kebangsaan Malaysia Medical Centre, Kuala Lumpur, Malaysia.

Published: 29 June 2011

doi:10.1186/1753-6561-5-S6-P212

Cite this article as: Sulong et al:: Surveillance of central-line associated bloodstream infections in ICU at a Malaysian medical centre. BMC

Proceedings 2011 5(Suppl 6):P212.

Submit your next manuscript to BioMed Central and take full advantage of:

- Convenient online submission

- Thorough peer review

- No space constraints or color figure charges

- Immediate publication on acceptance

- Inclusion in PubMed, CAS, Scopus and Google Scholar

- Research which is freely available for redistribution 